\title{
SLC47 family of multidrug and toxin extrusion transporters in GtoPdb v.2021.3
}

\author{
Ken-ichi Inui ${ }^{1}$ \\ 1. Kyoto Pharmaceutical University, Japan
}

\begin{abstract}
These proton:organic cation exchangers are predicted to have 13 TM segments [12] and are suggested to be responsible for excretion of many drugs in the liver and kidneys [1].
\end{abstract}

\section{Contents}

This is a citation summary for SLC47 family of multidrug and toxin extrusion transporters in the Guide to Pharmacology database (GtoPdb). It exists purely as an adjunct to the database to facilitate the recognition of citations to and from the database by citation analyzers. Readers will almost certainly want to visit the relevant sections of the database which are given here under database links.

GtoPdb is an expert-driven guide to pharmacological targets and the substances that act on them. GtoPdb is a reference work which is most usefully represented as an on-line database. As in any publication this work should be appropriately cited, and the papers it cites should also be recognized. This document provides a citation for the relevant parts of the database, and also provides a reference list for the research cited by those parts. For further details see [2].

Please note that the database version for the citations given in GtoPdb are to the most recent preceding version in which the family or its subfamilies and targets were substantially changed. The links below are to the current version. If you need to consult the cited version, rather than the most recent version, please contact the GtoPdb curators.

\section{Database links}

SLC47 family of multidrug and toxin extrusion transporters

https://www.guidetopharmacology.org/GRAC/FamilyDisplayForward?familyId=236

Transporters

MATE1(Multidrug and toxin extrusion)

https://www.guidetopharmacology.org/GRAC/ObjectDisplayForward?objectId=1216

MATE2-K(MATE2)

https://www.guidetopharmacology.org/GRAC/ObjectDisplayForward?objectId=1217

\section{References}

1. Alexander SPH, Kelly E, Mathie A, Peters JA, Veale EL, Armstrong JF, Faccenda E, Harding SD, Pawson AJ and Sharman JL et al.. (2019) THE CONCISE GUIDE TO PHARMACOLOGY 2019/20: Transporters. Br J Pharmacol 176 Suppl 1: S397-S493 [PMID:31710713]

2. Buneman P, Christie G, Davies JA, Dimitrellou R, Harding SD, Pawson AJ, Sharman JL and Wu Y. (2020) Why data citation isn't working, and what to do about it Database 2020 [PMID:32367113]

3. Chen Y, Zhang S, Sorani M and Giacomini KM. (2007) Transport of paraquat by human organic cation transporters and multidrug and toxic compound extrusion family.J Pharmacol Exp Ther 322: 695-700 [PMID:17495125]

4. Ito S, Kusuhara H, Kuroiwa Y, Wu C, Moriyama Y, Inoue K, Kondo T, Yuasa H, Nakayama H and Horita S et al.. (2010) Potent and specific inhibition of mMate1-mediated efflux of type I organic cations in the liver and kidney by pyrimethamine. J Pharmacol Exp Ther 333: 341-50 


\section{[PMID:20065018]}

5. Masuda S, Terada T, Yonezawa A, Tanihara Y, Kishimoto K, Katsura T, Ogawa O and Inui K. (2006) Identification and functional characterization of a new human kidney-specific $\mathrm{H}+/$ organic cation antiporter, kidney-specific multidrug and toxin extrusion 2. J Am Soc Nephrol 17: 212735 [PMID:16807400]

6. Ohta KY, Inoue K, Hayashi Y and Yuasa H. (2006) Molecular identification and functional characterization of rat multidrug and toxin extrusion type transporter 1 as an organic cation/H+ antiporter in the kidney. Drug Metab Dispos 34: 1868-74 [PMID:16928787]

7. Otsuka M, Matsumoto T, Morimoto R, Arioka S, Omote H and Moriyama Y. (2005) A human transporter protein that mediates the final excretion step for toxic organic cations. Proc Natl Acad Sci USA 102: 17923-8 [PMID:16330770]

8. Tanihara Y, Masuda S, Sato T, Katsura T, Ogawa O and Inui K. (2007) Substrate specificity of MATE1 and MATE2-K, human multidrug and toxin extrusions/H(+)-organic cation antiporters. Biochem Pharmacol 74: 359-71 [PMID:17509534]

9. Terada T, Masuda S, Asaka J, Tsuda M, Katsura T and Inui K. (2006) Molecular cloning, functional characterization and tissue distribution of rat $\mathrm{H}+$ /organic cation antiporter MATE1. Pharm Res 23: 1696-701 [PMID:16850272]

10. Tsuda M, Terada T, Ueba M, Sato T, Masuda S, Katsura T and Inui K. (2009) Involvement of human multidrug and toxin extrusion 1 in the drug interaction between cimetidine and metformin in renal epithelial cells. J Pharmacol Exp Ther 329: 185-91 [PMID:19164462]

11. Yasujima T, Ohta KY, Inoue K, Ishimaru M and Yuasa H. (2010) Evaluation of 4',6-diamidino-2phenylindole as a fluorescent probe substrate for rapid assays of the functionality of human multidrug and toxin extrusion proteins. Drug Metab Dispos 38: 715-21 [PMID:20047987]

12. Zhang $\mathrm{X}$ and Wright SH. (2009) MATE1 has an external COOH terminus, consistent with a 13helix topology. Am J Physiol Renal Physiol 297: F263-71 [PMID:19515813] 